GRASAS Y ACEITES 69 (4)

October-December 2018, e283

ISSN-L: 0017-3495

https://doi.org/10.3989/gya.0114181

\title{
Tendency of lipid radical formation and volatiles in lose or vacuum-packed Brazil nuts stored at room temperature or under refrigeration
}

\author{
A.G. de O. Sartori ${ }^{\mathrm{a}, \mathrm{c}}$, G.R. Sampaio ${ }^{\mathrm{b}}$, D.H.M. Bastos ${ }^{\mathrm{b}}$, M.H.F. Spoto ${ }^{\mathrm{a}}$, \\ L.H. Skibsted ${ }^{c}$ and M.A.B. Regitano d'Arce, ${ }^{a, \square}$ \\ ${ }^{a}$ Agri-Food Industry, Food and Nutrition Department, "Luiz de Queiroz" College of Agriculture, \\ University of São Paulo, Piracicaba, SP, Brazil. \\ ${ }^{b}$ Department of Nutrition, School of Public Health, University of São Paulo, São Paulo, SP, Brazil \\ ${ }^{c}$ Department of Food Science, Faculty of Science, University of Copenhagen, Frederiksberg, Denmark. \\ $\triangle$ Corresponding author: marisadarce@usp.br
}

SUMMARY: The Brazil nut is an important product from the Amazonian region and its productive chain is an income source for local communities. The effect of combinations of packaging atmospheres (loose or vacuum-packed) and storage temperatures $\left(4 \pm 1^{\circ} \mathrm{C}\right.$ or $\left.24 \pm 2{ }^{\circ} \mathrm{C}\right)$ on the tendency of lipid radical formation and on volatiles was investigated for the first time in shelled Brazil nut kernels. It was observed that refrigeration, whether combined with lose packing or vacuum packing, was effective to reduce the tendency for lipid radical formation, as detected by spin-trapping electron spin resonance (ESR) spectroscopy, as well as peroxides, conjugated dienes and 3-octen-2-one. However, the combination of refrigeration with vacuum packing, even using low-density polyethylene (LDPE) pouches with a high oxygen transmission rate (OTR), also reduced the formation of hexanal, which is a major off-flavor volatile, and thus should be recommended for the storage of Brazil nut kernels for the studied period.

KEYWORDS: ESR; Free radicals; Lipid oxidation; Nuts; Spin trapping

RESUMEN: Evolución en la formación de radicales lipídicos y pérdida de volátiles en nueces de Brasil empaquetadas al vacio y almacenadas a temperatura ambiente o refrigeradas. La nuez de Brasil es un producto importante de la región amazónica y su cadena productiva es fuente de ingresos para las comunidades locales. Se investigó por la primera vez el efecto de combinaciones de atmósferas de empaquetado (sueltas o empaquetadas al vacío) y temperaturas de almacenamiento $\left(4 \pm 1{ }^{\circ} \mathrm{Co} 24 \pm 2{ }^{\circ} \mathrm{C}\right)$ sobre la evolución de la formación de radicales lipídicos y en los volátiles en nueces de Brasil. Se observó que la refrigeración, en combinación con envasado solo o al vacío, fue eficaz para reducir la formación de radicales lipídicos, como se detectó mediante espectroscopía de resonancia magnética de espín (ESR), así como de peróxidos, dienos conjugados y 3-octen-2-ona. Sin embargo, la combinación de refrigeración con envasado al vacío, incluso utilizando bolsas de polietileno de baja densidad (LDPE) con alta velocidad de transmisión de oxígeno (OTR), también redujo la formación de hexanal, que es un volátil de sabor desagradable, por lo que debería recomendarse para el almacenamiento de almendras de Brasil durante el período estudiado.

PALABRAS CLAVE: ESR; Nueces; Oxidación lipídica; Radicales libres; Spin trapping

ORCID ID: Sartori AGO https://orcid.org/0000-0002-6782-5379, Sampaio GR https://orcid.org/0000-0002-7763-4664, Bastos DHM https://orcid.org/0000-0002-9095-2843, Spoto MHF https://orcid.org/0000-0001-9219-6343, Skibsted LH https://orcid.org/0000-0003-1734-5016, Regitano-d'Arce MAB https://orcid.org/0000-0001-6801-6277

Citation/Cómo citar este artículo: Sartori AGO, Sampaio GR, Bastos DHM, Spoto MHF, Skibsted LH, Regitanod'Arce MAB. 2018. Tendency of lipid radical formation and volatiles in lose or vacuum-packed Brazil nuts stored at room temperature or under refrigeration. Grasas Aceites 69 (4), e283. https://doi.org/10.3989/gya.0114181

Copyright: (C2018 CSIC. This is an open-access article distributed under the terms of the Creative Commons Attribution 4.0 International (CC BY 4.0) License. 


\section{INTRODUCTION}

Brazil nuts are the seeds of the Bertholletia excelsa Humb. \& Bonpl. tree (family of Lecythidaceae) and originated in the Amazonian region. In Brazil, native people collect most of commercialized seeds as they fall from the trees in natural rainforests and no deforestation is needed (FAO, 2013). Global production of in-shell Brazil nuts has doubled in 25 years, from 49,740 tons in 1989 to 109,300 tons in 2014, and Brazil was the second largest producer, with an output of 39,000 tons in 2014 (FAO, 2017).

Regarding biochemical composition, the Brazil nut kernel is the greatest food source of selenium, which plays a key role as cofactor for antioxidant glutathione peroxidase (Rotruck et al., 1973). Selenium also has antiviral effects, may be essential for human reproduction, and may reduce the risk of autoimmune thyroid disease (Rayman, 2012). Brazil nuts contain high contents of n-6 and n-9 fatty acids, vitamin E, magnesium, phosphorus, zinc, manganese, and sulphur-containing amino acids (USDA, 2015), besides bioactive compounds, such as phytoesterols (da Costa et al., 2010).

As Brazil nut kernels have high lipid contents $(60-70 \%)$, of which around $40 \%$ is linoleic acid (USDA, 2015), they tend to oxidize easily (Vieira and Regitano-d'Arce, 1999). Therefore, postharvest practices regarding storage, such as air removal and refrigeration, determinately influence the shelf life of the kernels by retarding the formation of hydroperoxides, which are decomposed to off-flavor volatiles. Despite the growing market importance and nutritional relevance, few studies have investigated the effect of storage on oxidative changes in Brazil nuts (Ribeiro et al., 1993a, Ribeiro et al., 1993b, Ribeiro et al., 1995, Zajdenwerg et al., 2011), and there were no studies found on the tendency for lipid radical formation or volatiles under commercial retail conditions. The tendency for the formation of lipid free radicals, which are precursors of hydroperoxides, can be monitored by electron spin resonance (ESR) spectroscopy, which is a sensitive (minimum detectable concentration of radicals is around $10^{-9} \mathrm{M}$ under optimal conditions) and solvent-free method (Andersen and Skibsted, 2002). For oils and liquids, a spin trap compound capable of complexing with short-lived free radicals to form long-lived spin adducts that are detected by ESR is used (Velasco et al., 2004). ESR spectroscopy has been used to detect radical species in several oils, beer and dried foods, but not to evaluate the oxidative stability of nuts (Andersen and Skibsted, 2018).

Therefore, the objective of the present study was to investigate for the first time the effect of retail storage conditions on the tendency for lipid radical formation and on volatiles in shelled Brazil nut kernels.

\section{MATERIALS AND METHODS}

\subsection{Materials}

One metalized vacuum-packed bag of $20 \mathrm{~kg}$ of fresh and shelled Brazil nut kernels of small size (at least 68 kernels in $453 \mathrm{~g}$ ) was purchased from a local market. After thorough mixing, portions of the kernels $(300 \mathrm{~g})$ were placed in low-density polyethylene (LDPE) pouches, which are commonly used as packaging material, vacuum or loose, for nuts in Brazil, with an estimated oxygen transmission rate (OTR) of $9843 \mathrm{~cm}^{3} / \mathrm{m}^{2} / 24 \mathrm{~h}$ (at $23{ }^{\circ} \mathrm{C}$ and $0 \%$ relative humidity). The Kernels were vacuum or loosepacked on a sealing machine (model 300 B, Selovac, São Paulo, Brazil) and stored in the dark at ambient temperature $\left(24 \pm 2{ }^{\circ} \mathrm{C}\right)$ and under refrigeration $\left(4 \pm 1^{\circ} \mathrm{C}\right)$. Therefore, four treatments were evaluated:

Ambient temperature, loose packing (treatment AL)

Refrigerated temperature, loose packing (treatment RL)

Ambient temperature, vacuum packing (treatment AV)

Refrigerated temperature, vacuum packing (treatment RV)

Temperature was monitored using a thermo hygrometer (Incoterm, Porto Alegre, Brazil), and the effectiveness of the sealing was checked by visually evaluating the formation of air bubbles when submerging an extra pouch (not used in the study) in water after sealing each three pouches. Every 30 days and during four months, samples were collected and $200 \mathrm{~g}$ were chopped in a domestic mixer and stored under vacuum in LDPE pouches, while $100 \mathrm{~g}$ were cold pressed with a hydraulic press (Carver, Wabash, USA) under up to $172 \mathrm{MPa}$ and the obtained oil was filtered and stored in Eppendorf flasks. The chopped kernels and the cold pressed oils were kept at $-18{ }^{\circ} \mathrm{C}$ in the dark until analysis. All chemicals were analytical grade or higher as required.

\subsection{Fatty acid profile}

The composition of fatty acid methyl esters (FAME) in the cold-pressed oil was assessed at time zero and after four months of storage. FAME were prepared based on the method described by Hartman and Lago (1973). A saponification (2 g sodium hydroxide diluted in $100 \mathrm{~mL}$ methanol), an esterification $(4 \mathrm{~g}$ ammonium chloride diluted in $120 \mathrm{~mL}$ methanol and added with $6 \mathrm{~mL}$ sulfuric acid were added in a round glass flask, shaken, boiled under reflux and shaken again for $15 \mathrm{~min}$ ) and a saturated saline solution (36 g sodium chloride diluted in $100 \mathrm{~mL}$ deionized water) were used. In a tube with a gas-tight lid (tube 1), approximately $50 \mathrm{mg}$ of oil and $2 \mathrm{~mL}$ of the saponification solution were added, shaken, and heated at $100{ }^{\circ} \mathrm{C}$ for 5 min and cooled down in running water to $30-40^{\circ} \mathrm{C}$. 
Then, $2.5 \mathrm{~mL}$ of the esterification solution were added to tube 1, which was shaken, heated again at $100{ }^{\circ} \mathrm{C}$ for $5 \mathrm{~min}$ and cooled down in running water to $30-40{ }^{\circ} \mathrm{C}$. Tube 1 was added with $5 \mathrm{~mL} n$-hexane, shaken, added with $5 \mathrm{~mL}$ of the saline solution, and again carefully shaken to avoid emulsification. The supernatant was transferred to tube 2 with a gastight lid, $5 \mathrm{~mL}$ deionized water were added and the solution was held until phase separation occurred. At this point, the supernatant was transferred to a third tube with a gas-tight lid (tube 3), $0.5 \mathrm{~g}$ anhydrous sodium sulphate was added and it was gently swirled. Finally, the FAME solution (supernatant of tube 3) was collected and transferred to an Eppendorf flask, which was flushed with $\mathrm{N}_{2}$ and kept at $-18^{\circ} \mathrm{C}$ until $\mathrm{GC}$ analysis.

GC analysis: FAME solution $(1 \mathrm{~mL})$ was added to $0.1 \mathrm{~mL}$ of a solution of methyl tridecanoate (T0627, Sigma-Aldrich, St. Louis, USA) diluted in $n$-hexane $(2.5 \mathrm{mg} / \mathrm{mL})$, as internal standard. It was injected into a GC-2010 Plus gas chromatograph (Shimadzu, Kyoto, Japan) equipped with a flame ionization detector (FID). Separation was achieved on a RtxWax capillary column $(30 \mathrm{~m} \times 0.32 \mathrm{~mm}, 0.25 \mu \mathrm{m})$ (Restek, Bellefonte, USA). Nitrogen was the carrier gas at a flow rate of $1.2 \mathrm{~mL} / \mathrm{min}$, and the injected sample volume was $1 \mu \mathrm{L}$ (split 1:20). Initial column oven temperature $\left(60^{\circ} \mathrm{C}\right)$ was raised to $210{ }^{\circ} \mathrm{C}$ at $20{ }^{\circ} \mathrm{C} / \mathrm{min}$ and held for $7 \mathrm{~min}$, and then raised to $240{ }^{\circ} \mathrm{C}$ at $30^{\circ} \mathrm{C} / \mathrm{min}$ rate and held for $12 \mathrm{~min}$. Both injector and FID temperatures were set at $250^{\circ} \mathrm{C}$. FAME were identified using the peak retention times of the standard FAME mix GLC-87 (Nu-Chek, Elysian, USA), as reference. Before sample injection, a first run was made with a standard FAME mix diluted in $n$-hexane $(10 \mathrm{mg} / \mathrm{mL})$ and added to the internal standard solution. Quantification was performed by area normalization.

\subsection{Tendency of lipid radical formation}

The spin-trapping ESR method was based on procedures described by Thomsen et al., (2000), with modifications. Cold-pressed oil ( $1 \mathrm{~g})$ was gently swirled with $1 \mathrm{mg}$ of $\mathrm{N}$-tert-butyl- $\alpha$-phenylnitrone (PBN) (80126, Sigma-Aldrich, St. Louis, USA) in brown Eppendorf flasks and kept submerged in a thermostatted water bath at $70{ }^{\circ} \mathrm{C}$. After $5 \mathrm{~h}$, $50 \mu \mathrm{L}$ were transferred to capillary micropipettes (Blaubrand, Wertheim, Germany) and measured on a MiniScope MS200 ESR spectrometer (Magnettech, Berlin, Germany). The acquisition parameters were center field $3336.90 \mathrm{G}$; sweep width of $66.42 \mathrm{G}$; sweep time of $30 \mathrm{~s}$; and modulation amplitude of $1 \mathrm{G}$. The microwave power was kept at $445 \pm 1 \mathrm{MHz}$. Each measurement was performed as an average of six sweeps. Results were expressed as the height of the first peak in the spectra after $5 \mathrm{~h}$ of incubation (see an example at Figure 1), since peak

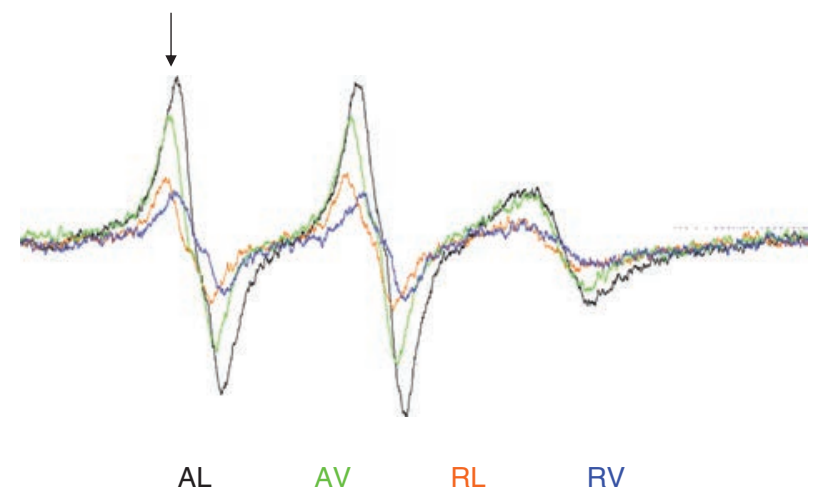

FIgURE 1. Overlap of the ESR spectra of the treatments after 4 months and the peak used to determine the tendency of lipid radical formation (indicated by the vertical arrow).

AL: Ambient conditions and loose packing; RL: Refrigerated temperature and loose packing; AV: Ambient conditions and vacuum packing; RV: Refrigerated temperature and vacuum packing.

height is related to spin adduct concentration and can be used to compare similar samples (Thomsen, Kristensen and Skibsted, 2000).

\subsection{Primary lipid oxidation products}

Peroxide value (PV) was measured according to the method described by Shantha and Decker (1994), with modifications comprehensively described by Zajdenwerg et al., (2011). This spectrophotometric method is more sensitive than the traditional iodometric titration method (Dobarganes and Velasco, 2002). Measurement was taken at $510 \mathrm{~nm}$ and quantification was carried out by building a standard curve prepared with cumene hydroperoxide solutions $\left(\mathrm{R}^{2}=0.999\right)$.

Specific absorption at $232 \mathrm{~nm}\left(\mathrm{~K}_{232}\right)$ was determined according to standard method ISO 3656:2011, and the solvent was $n$-hexane. For both analyses, a Shimadzu UV 1203 spectrophotometer (Kyoto, Japan) was used.

\subsection{Volatile aroma compounds (VACs)}

The procedures to concentrate and measure VAC formation were based on a method described by de Camargo et al., (2016). For VAC concentration, $2 \mathrm{~g}$ of cold pressed oil were added to a $20 \mathrm{~mL}$ vial which was flushed with nitrogen for $10 \mathrm{~s}$ and immediately capped with a gas-tight aluminum lid with silicone septum. The vial was kept immersed in a thermostatted water bath at $80{ }^{\circ} \mathrm{C}$ under magnetic stirring for $20 \mathrm{~min}$. Then, a solid-phase microextraction (SPME) assembly composed of a divinylbenzene/ carboxen/polydimethylsiloxane (DVB/CAR/PDMS, $50 / 30 \mu \mathrm{m}$ ) fiber (Supelco, Bellefonte, USA) was inserted through the septum and exposed to the headspace for $10 \mathrm{~min}$ at $80{ }^{\circ} \mathrm{C}$. This fiber was 
inserted into the injector of a GC-2010 gas chromatograph (Shimadzu, Kyoto, Japan) coupled to a mass spectrometer QP 2010 Plus (Shimadzu, Kyoto, Japan) and separation was achieved on a Rtx-5MS capillary column $(30 \mathrm{~m} \times 0.25 \mathrm{~mm}, 0.25 \mu \mathrm{m})($ Restek, Bellefonte, USA). Helium was used as carrier gas at a flow rate of $1 \mathrm{~mL} / \mathrm{min}$, and the injected sample volume was $1 \mu \mathrm{L}$ (splitless mode). Initial column oven temperature $35^{\circ} \mathrm{C}$ was held for $3 \mathrm{~min}$, raised to $60^{\circ} \mathrm{C}$ $\left(5^{\circ} \mathrm{C} / \mathrm{min}\right.$ ) and held for $3 \mathrm{~min}$, then raised to $200^{\circ} \mathrm{C}$ $\left(8{ }^{\circ} \mathrm{C} / \mathrm{min}\right)$ and held for $10 \mathrm{~min}$, and then raised to $280{ }^{\circ} \mathrm{C}\left(20{ }^{\circ} \mathrm{C} / \mathrm{min}\right)$ and held for $5 \mathrm{~min}$. Injector and ion source temperatures were set to $270{ }^{\circ} \mathrm{C}$ and $200^{\circ} \mathrm{C}$, respectively. Spectral data were obtained over a mass range from 20 to $300 \mathrm{~m} / \mathrm{z}$. Every day a blank (a vial without sample submitted under exactly the same conditions) was run before starting analyses. Peaks were tentatively identified by both mass spectra and linear retention index (LRI). Mass spectra were matched with those from Wiley Library (Version 8), considering $85 \%$ similarity as the cut-off. LRI was calculated relatively to the standard n-alkane series (Babushok et al., 2011), and compared with literature data (Elmore et al., 2000; Ventanas et al., 2007; Babushok et al., 2011; Georgiadou et al., 2015), considering differences of $2 \%$ as cut-off. Hexanal and trans-2-heptenal identities were confirmed by spiking Brazil nut oil samples with reference standards (codes 115606 and 90244, respectively, both from Sigma-Aldrich, St. Louis, USA). Relative amounts were represented in terms of peak area.

\subsection{Sensory analysis}

A panel composed of seven assessors evaluated the samples of chopped kernels. Criteria to choose assessors were to be familiar with sensory analysis, Brazil nuts and rancid odor in foods. A type I incomplete Latin square $(\mathrm{t}=21 ; \mathrm{k}=5 ; \mathrm{r}=5 ; \mathrm{b}=21$;
$\Lambda=1, \mathrm{E}=0.84)$ design was used (Cochran and Cox, 1964), considering 16 samples (4 treatments $\times 4$ months) +5 time zero samples (control). Each assessor analyzed three random blocks with five samples each. Rancid odor was the attribute evaluated using a 10-point scale (from 1 to 10), with assessors having access to reference samples of fresh (point 1 of the scale) and highly rancid (point 10 of the scale) kernels. Assessments were conducted in individual booths with monochromatic red light in order to minimize sample color effect. The protocol for this study was previously approved by the Committee of Ethics in Research of the Luiz de Queiroz College of Agriculture (Process n. 47619515.2.0000.5395).

\subsection{Statistical analysis}

In order to choose the most appropriate statistical tests, all data were first checked for normality, which is the likelihood that the data be distributed normally, by Ryan-Joyner's test, and for homoscedasticity, which is homogeneity of variances, by Bartlett's test. As all data were parametric, mean values were evaluated by analysis of variance (oneway ANOVA), and, in case of mean differences, Tukey's test was used. Pearson correlation was tested between PV, $\mathrm{K}_{232}$ and ESR analysis data. The level of confidence of 0.05 was considered and all statistical analyses were determined using Minitab ${ }^{\circledR}$ 17 software (Minitab Inc., State College, USA).

\section{RESULTS AND DISCUSSION}

\subsection{Fatty acid profile}

The composition of major fatty acids was determined at time zero and after four months of storage (Table 1). At time zero, the cold pressed oil was majorly composed of linoleic acid $(\sim 39 \%)$,

TABLE 1. Composition of major fatty acids in shelled Brazil nuts stored under different temperatures and atmospheres

\begin{tabular}{lrrrrr}
\hline & & \multicolumn{1}{c}{ 4 months } \\
\cline { 3 - 6 } Fatty acid & \multicolumn{1}{c}{ Time zero } & \multicolumn{1}{c}{$\mathbf{A L}$} & \multicolumn{1}{c}{ RL } & \multicolumn{1}{c}{ AV } & RV \\
\hline Palmitic (C16:0) & $15.91 \pm 0.03$ & $17.09 \pm 0.02$ & $16.23 \pm 0.00$ & $16.44 \pm 0.02$ & $15.94 \pm 0.02$ \\
Palmitoleic (C16:1) & $0.37 \pm 0.00$ & $0.38 \pm 0.00$ & $0.37 \pm 0.00$ & $0.43 \pm 0.00$ & $0.35 \pm 0.00$ \\
Stearic (C18:0) & $11.30 \pm 0.01$ & $12.17 \pm 0.02$ & $10.78 \pm 0.02$ & $11.33 \pm 0.03$ & $11.67 \pm 0.01$ \\
Oleic (C18:1) & $32.83 \pm 0.02$ & $30.94 \pm 0.00$ & $32.56 \pm 0.00$ & $32.60 \pm 0.01$ & $32.44 \pm 0.05$ \\
Linoleic (C18:2) & $39.35 \pm 0.00$ & $39.15 \pm 0.04$ & $39.82 \pm 0.02$ & $38.96 \pm 0.06$ & $39.35 \pm 0.04$ \\
Arachidic (C20:0) & $0.25 \pm 0.00$ & $0.26 \pm 0.00$ & $0.23 \pm 0.00$ & $0.24 \pm 0.00$ & $0.25 \pm 0.00$ \\
$\sum_{\text {SFA }}$ & $27.45 \pm 0.02$ & $29.53 \pm 0.04$ & $27.24 \pm 0.02$ & $28.01 \pm 0.04$ & $27.85 \pm 0.01$ \\
$\sum_{\text {MUFA }}$ & $33.20 \pm 0.02$ & $31.32 \pm 0.00$ & $32.94 \pm 0.00$ & $33.03 \pm 0.01$ & $32.80 \pm 0.05$ \\
$\sum_{\text {PUFA }}$ & $39.35 \pm 0.00$ & $39.15 \pm 0.04$ & $39.82 \pm 0.02$ & $38.96 \pm 0.06$ & $39.35 \pm 0.04$ \\
\hline
\end{tabular}

Results expressed as mean \pm standard deviation $(\mathrm{n}=2)$ of percent mass of total fatty acid mass. SFA: Total saturated fatty acids; MUFA: Total monounsaturated fatty acids; PUFA: Total polyunsaturated fatty acids. AL: Ambient conditions and loose packing; RL: Refrigerated temperature and loose packing; AV: Ambient conditions and vacuum packing; RV: Refrigerated temperature and vacuum packing. 
oleic acid $(\sim 32 \%)$, palmitic acid $(\sim 16 \%)$ and stearic acid $(\sim 11 \%)$, and these results are similar to those reported in the literature for Brazil nut oils extracted whether by cold pressing or with organic solvents (Miraliakbari and Shahidi, 2008; Santos et al., 2012; USDA, 2015). Although linoleic acid is known to be an essential nutrient, the high content of this fatty acid makes the kernels susceptible to oxidation, since they contain one hydrogen atom attached to a carbon between double bonds, which requires the lowest activation energy for the initiation of alkyl radical formation and, consequently, fatty acid deterioration (Choe and Min, 2006).

After four months of storage, the fatty acid profile showed small alterations when compared with time zero (Table 1), which corroborates similar results of iodine value for the degree of unsaturation observed in Brazil nut oil and in other nut oils during long-term storage (Fourie and Basson 1989; Ribeiro and others 1993b). Therefore, as expected, the fatty acid profile analysis was not sufficient to indicate oxidative changes in the lipid fraction of Brazil nuts stored under retail conditions for four months.

\subsection{Tendency for lipid radical formation}

To the best of our knowledge, this was the first time ESR spectroscopy was used to measure radical species in Brazil nut kernels and in nuts in general (Andersen and Skibsted, 2018). Firstly, a nondestructive direct measurement in the ESR spectrometer was tested using chopped kernels placed in ESR tubes with a $4 \mathrm{~mm}$ inner diameter (Wilmad Glass Company, Buena, USA), with notes taken for height and weight to measure density. Nevertheless, low and similar peaks were observed in the ESR spectra (data not shown), which may be due to the exposure of the short-lived radical species to oxygen during chopping, therefore hindering detection by ESR (Andersen and Skibsted, 2002). Thus, the ESR technique using PBN as the spin trap was employed.

Results for the tendency for radical formation are shown in Table 2. The kernels stored under refrigeration (treatments RL and RV) presented a lower tendency for lipid radical formation throughout storage. On the other hand, the kernels stored under ambient conditions (treatments AL and AV) showed a sharp increase during the first month and it kept

TABLE 2. Tendency of lipid radical formation, peroxide value and specific extinction at $232 \mathrm{~nm}$ in Brazil nuts stored under different temperatures and atmospheres

\begin{tabular}{lcccc}
\hline \multicolumn{5}{c}{ Tendency of lipid radical formation (a.u.) } \\
\hline Time (months) & AL & RL & AV & RV \\
\hline 0 & $5.37 \pm 0.44^{\mathrm{D}}$ & $5.37 \pm 0.44^{\mathrm{B}}$ & $5.37 \pm 0.44^{\mathrm{D}}$ & $5.37 \pm 0.44^{\mathrm{B}}$ \\
1 & $9.37 \pm 0.28^{\mathrm{Ca}}$ & $5.16 \pm 0.07^{\mathrm{Bb}}$ & $8.94 \pm 0.00^{\mathrm{Ca}}$ & $5.03 \pm 0.00^{\mathrm{Bb}}$ \\
2 & $10.04 \pm 0.10^{\mathrm{Cb}}$ & $4.07 \pm 0.11^{\mathrm{Cc}}$ & $11.40 \pm 0.07^{\mathrm{Ba}}$ & $4.79 \pm 0.02^{\mathrm{Bc}}$ \\
3 & $13.70 \pm 0.11^{\mathrm{Ba}}$ & $4.42 \pm 0.10^{\mathrm{Cb}}$ & $13.31 \pm 0.33^{\mathrm{Aa}}$ & $5.71 \pm 0.49^{\mathrm{Bb}}$ \\
4 & $18.06 \pm 0.21^{\mathrm{Aa}}$ & $6.09 \pm 0.11^{\mathrm{Ac}}$ & $13.61 \pm 0.04^{\mathrm{Ab}}$ & $6.93 \pm 0.40^{\mathrm{Ac}}$ \\
\hline
\end{tabular}

\begin{tabular}{lcccc}
\hline \multicolumn{4}{c}{ Peroxide value (meq $\mathbf{~} \mathbf{2} / \mathbf{k g}$ oil) } \\
\hline Time (months) & $\mathbf{A L}$ & $\mathbf{R L}$ & $\mathbf{A V}$ & $\mathbf{R V}$ \\
\hline 0 & $2.68 \pm 0.18^{\mathrm{C}}$ & $2.68 \pm 0.18^{\mathrm{B}}$ & $2.68 \pm 0.18^{\mathrm{C}}$ & $2.68 \pm 0.18^{\mathrm{A}}$ \\
1 & $3.88 \pm 0.27^{\mathrm{Ba}}$ & $2.16 \pm 0.11^{\mathrm{CDbc}}$ & $2.64 \pm 0.21^{\mathrm{Cb}}$ & $2.17 \pm 0.10^{\mathrm{Bc}}$ \\
2 & $4.68 \pm 0.31^{\mathrm{Bb}}$ & $2.32 \pm 0.03^{\mathrm{Cc}}$ & $5.47 \pm 0.34^{\mathrm{Ba}}$ & $2.03 \pm 0.19^{\mathrm{Bc}}$ \\
3 & $4.44 \pm 0.24^{\mathrm{Bb}}$ & $3.16 \pm 0.14^{\mathrm{Ac}}$ & $5.91 \pm 0.50^{\mathrm{Ba}}$ & $1.46 \pm 0.06^{\mathrm{Cd}}$ \\
4 & $9.86 \pm 0.70^{\mathrm{Aa}}$ & $1.98 \pm 0.10^{\mathrm{Dc}}$ & $8.12 \pm 0.07^{\mathrm{Ab}}$ & $2.77 \pm 0.00^{\mathrm{Ac}}$ \\
\hline & & Specific extinction at 232 nm (a.u.) & $\mathbf{R V}$ \\
\hline Time (months) & $\mathbf{R L}$ & $\mathbf{A V}$ & $3.16 \pm 0.03^{\mathrm{C}}$ \\
\hline 0 & $3.16 \pm 0.03^{\mathrm{E}}$ & $3.16 \pm 0.03^{\mathrm{B}}$ & $3.16 \pm 0.03^{\mathrm{D}}$ & $3.13 \pm 0.02^{\mathrm{Cc}}$ \\
1 & $3.95 \pm 0.03^{\mathrm{Da}}$ & $3.13 \pm 0.00^{\mathrm{Bc}}$ & $3.81 \pm 0.09^{\mathrm{Cb}}$ & $2.91 \pm 0.09^{\mathrm{Dc}}$ \\
3 & $4.38 \pm 0.09^{\mathrm{Cb}}$ & $2.81 \pm 0.10^{\mathrm{Cc}}$ & $5.00 \pm 0.09^{\mathrm{Ba}}$ & $3.37 \pm 0.12^{\mathrm{Bb}}$ \\
\hline
\end{tabular}

Results expressed as mean \pm standard deviation $(n=3)$. Means followed by different superscript upper-case letters within the same column are significantly different. Means followed by different superscript lower-case letters within the same row are significantly different. a.u.: adimensional unit. Statistical tests used: one-way ANOVA and Tukey's test, with a level of confidence of 0.05. AL: Ambient conditions and loose packing; RL: Refrigerated temperature and loose packing; AV: Ambient conditions and vacuum packing; RV: Refrigerated temperature and vacuum packing. 
increasing up to the third month. Thereafter, radical formation continued to increase for AL, while it remained stable for $\mathrm{AV}$, with significant differences between these treatments during the fourth months. Therefore, vacuum packing did not affect the tendency for lipid radical formation during refrigerated storage up to four months and during room temperature storage of at least up to three months.

Although the identification of the trapped free radicals are hindered due to their addition to the PBN molecule (Andersen and Skibsted, 2002), it is suggested PBN traps mainly peroxyl radicals, which are formed from the very fast reaction of alkyl radicals with oxygen (Velasco et al., 2005). During lipid oxidation, peroxyl radicals abstract one hydrogen atom from unsaturated fatty acids, forming hydroperoxides and another alkyl radical, propagating lipid deterioration (Choe and Min, 2006).

\subsection{Primary lipid oxidation products}

Table 2 also comprises the results for PV and $\mathrm{K}_{232}$, which represent the total content of peroxides and the total content of conjugated dienes, respectively. $\mathrm{PV}$ at time zero $\left(2.68 \pm 0.18 \mathrm{meq} \mathrm{O}_{2} / \mathrm{kg}\right)$ was similar to the PV reported for cold-pressed oil extracted from fresh Brazil nut kernels (Gutierrez, Regitano-d'Arce and Rauen-Miguel, 1997), which confirms the fresh quality of the used Brazil nuts.

During the first month, PV slightly increased for $\operatorname{AL}\left(3.88 \pm 0.27 \mathrm{meq} \mathrm{O}_{2} / \mathrm{kg}\right)$ and remained low for the other treatments, with values varying from $2.16 \pm 0.11 \mathrm{meq} \mathrm{O}_{2} / \mathrm{kg}$ for RL to $2.64 \pm 0.21 \mathrm{meq} \mathrm{O}_{2} /$ $\mathrm{kg}$ for AV. Thereafter, the PV for kernels stored under refrigeration ( $R L$ and $R V$ ) tended to remain low during the entire storage, not exceeding 3.16 meq $\mathrm{O}_{2} / \mathrm{kg}$. For AL, the PV remained low from the first to the third month (from 3.88 to 4.68 meq $\mathrm{O}_{2} /$ $\mathrm{kg}$ ) and then sharply increased during the fourth month, reaching $9.86 \pm 0.70 \mathrm{meq} \mathrm{O}_{2} / \mathrm{kg}$. Meanwhile, it continued to increase, reaching $8.12 \pm 0.07 \mathrm{meq}$ $\mathrm{O}_{2} / \mathrm{kg}$ after four months for AV. Thus, as expected, refrigeration prevented peroxide formation in stored kernels, which is in agreement with Ribeiro et al. (1993a) who observed the effectiveness of refrigeration when compared to room temperature in preventing peroxide formation in Brazil nuts packed in paperboard for four months.

In contrast, vacuum did not show the expected protective effect for $\mathrm{AV}$, most likely due to the relatively high OTR of the LDPE pouches used, which might not have properly maintained a vacuum atmosphere within the package over time, although OTR was not estimated during storage to confirm this hypothesis. Chun et al., (2005) reported that even low contents of residual oxygen were enough to form peroxides in fresh peanuts containing low initial PV and stored under vacuum. Accordingly, reducing headspace oxygen from 2 to $1 \%$ proved to be more efficient than reduction from 21 to $2 \%$ on the lipid oxidation rate of linoleic acid (Marcuse and Fredriksson, 1968). Overall, PV values were below the maximum value of $15 \mathrm{meq} \mathrm{O}_{2} / \mathrm{kg}$ as defined by the Codex Alimentarius for commercial coldpressed vegetable oils (Codex Alimentarius, 2001), which indicates that the Brazil nuts remained suitable for consumption over storage and that the reported changes in this study concern the early stages of nut deterioration.

Another method for measuring primary lipid oxidation products is $\mathrm{K}_{232}$, which is based on the property of conjugated diene hydroperoxides formed in oils containing linoleic acid to give rise to an absorption peak at $232 \mathrm{~nm}$ in the ultraviolet region. The results for $\mathrm{K}_{232}$ are comprised in Table 2 and clearly show the effect of temperature on this parameter, as $\mathrm{K}_{232}$ remained low for up to four months for kernels stored under refrigeration (treatments RL and RV) and significantly increased for kernels stored under room temperature (treatments AL and $\mathrm{AV})$. Although it is known that the hydroperoxides formed during lipid autoxidation are conjugated dienes (Choe and Min, 2006), $\mathrm{K}_{232}$ significantly correlated with PV only for treatments under ambient conditions (AL: $r=0.875$ and $\mathrm{AV}: \mathrm{r}=0.925$ ) at a level of confidence of 0.05 .

However, the $\mathrm{K}_{232}$ results were similar to those found for the tendency of lipid radical formation, and this similarity was confirmed by high correlation coefficients between these methods for all treatments at a level of confidence of 0.01 (AL: 0.980; AV: 0.975; RL: 0.876, RV: 0.851). Stronger correlations between $\mathrm{K}_{232}$ and the ESR analysis than between PV and the ESR analysis were also observed for coldpressed Brazil nut oils stored in brown glass bottles at room temperature (Sartori et al., 2018). One hypothesis for the strong correlation between $\mathrm{K}_{232}$ and the ESR analysis for Brazil nut kernels is that peroxyl radicals, although very unstable, might have been detected as well as by $\mathrm{K}_{232}$, since these radical species are conjugated dienes (Evans et al., 1985).

\subsection{Volatile aroma compounds (VACs)}

The VACs detected by HS-SPME-GC-MS in the kernels were aldehydes, ketones, alcohols and pyrroles, as shown at Table 3. Almost all the samples presented formation of the same compounds, except for 2-decanone at time zero, and it varied according to treatment and time of storage. Other identified VACs, which were not included in Table 3, were hydrocarbons, since their thresholds are generally high and they are unlikely flavor contributors to Brazil nut kernels (Clark and Nursten, 1976).

Aldehydes are important VACs related to (off)flavor in foods, and some of them, such as hexanal, which is a major product from linoleic acid oxidation, are used as markers for secondary lipid 
Tendency of lipid radical formation and volatiles in lose or vacuum-packed Brazil nuts stored at room temperature 7

TABLE 3. Volatile aroma compounds in shelled Brazil nuts stored under different temperatures and atmospheres

\begin{tabular}{|c|c|c|c|c|c|c|c|}
\hline Volatile aroma compounds & LRI & Treatment & Time zero & 1 month & 2 months & 3 months & 4 months \\
\hline \multicolumn{8}{|l|}{ Aldehydes } \\
\hline \multirow[t]{4}{*}{ Hexanal $^{*}$} & 800.8 & $\mathrm{AL}$ & $2878 \pm 129^{d}$ & $4029 \pm 170^{\mathrm{Ac}}$ & $4568 \pm 142^{\mathrm{Ab}}$ & $5391 \pm 231^{\mathrm{Aa}}$ & $5268 \pm 320^{\mathrm{Ba}}$ \\
\hline & & RL & $2878 \pm 129^{\mathrm{d}}$ & $3760 \pm 289^{\mathrm{Ac}}$ & $4227 \pm 324^{\mathrm{Abc}}$ & $4513 \pm 233^{\mathrm{Bb}}$ & $5760 \pm 293^{\mathrm{Aa}}$ \\
\hline & & $\mathrm{AV}$ & $2878 \pm 129^{c}$ & $4279 \pm 141^{\mathrm{Ab}}$ & $4443 \pm 304^{\mathrm{Aab}}$ & $4489 \pm 232^{\mathrm{Bab}}$ & $4959 \pm 233^{\mathrm{Ba}}$ \\
\hline & & $\mathrm{RV}$ & $2878 \pm 129^{c}$ & $2829 \pm 165^{\mathrm{Bc}}$ & $3198 \pm 126^{\mathrm{Bb}}$ & $3525 \pm 6^{\mathrm{Ca}}$ & $2836 \pm 320^{\mathrm{Cc}}$ \\
\hline \multirow[t]{4}{*}{ Trans-2-heptenal ${ }^{*}$} & 960.3 & $\mathrm{AL}$ & $390 \pm 15^{\mathrm{b}}$ & $373 \pm 15^{\mathrm{BCb}}$ & $401 \pm 13^{\mathrm{Bb}}$ & $451 \pm 13^{\text {Аa }}$ & $472 \pm 18^{\mathrm{Ba}}$ \\
\hline & & RL & $390 \pm 15^{\mathrm{b}}$ & $377 \pm 20^{\mathrm{Bb}}$ & $385 \pm 10^{\mathrm{BCb}}$ & $465 \pm 33^{\mathrm{Aa}}$ & $422 \pm 23^{\mathrm{Cab}}$ \\
\hline & & $\mathrm{AV}$ & $390 \pm 15^{b}$ & $476 \pm 19^{\mathrm{Aa}}$ & $467 \pm 17^{\mathrm{Aa}}$ & $462 \pm 23^{\mathrm{Aa}}$ & $507 \pm 3^{\mathrm{Aa}}$ \\
\hline & & $\mathrm{RV}$ & $390 \pm 15^{\mathrm{a}}$ & $325 \pm 21^{\mathrm{Cb}}$ & $349 \pm 23^{\mathrm{Cab}}$ & $310 \pm 6^{\mathrm{Bb}}$ & $368 \pm 13^{\mathrm{Da}}$ \\
\hline \multirow[t]{4}{*}{ Trans-2-octenal } & 1060.9 & $\mathrm{AL}$ & $51 \pm 4^{\mathrm{e}}$ & $90 \pm 6^{\mathrm{Bd}}$ & $110 \pm 5^{\mathrm{Ac}}$ & $158 \pm 12^{\mathrm{Aa}}$ & $129 \pm 5^{\mathrm{Bb}}$ \\
\hline & & RL & $51 \pm 4^{\mathrm{d}}$ & $91 \pm 7^{\mathrm{Bc}}$ & $118 \pm 15^{\mathrm{Abc}}$ & $146 \pm 14^{\mathrm{Ab}}$ & $201 \pm 16^{\mathrm{Aa}}$ \\
\hline & & AV & $51 \pm 4^{c}$ & $123 \pm 8^{\mathrm{Aab}}$ & $106 \pm 2^{\mathrm{Ab}}$ & $135 \pm 5^{\mathrm{Aa}}$ & $124 \pm 13^{\mathrm{Bab}}$ \\
\hline & & RV & $51 \pm 4^{c}$ & $104 \pm 15^{\mathrm{Aba}}$ & $101 \pm 1^{\mathrm{Aa}}$ & $81 \pm 0^{\mathrm{Bb}}$ & $92 \pm 2^{\mathrm{Cab}}$ \\
\hline \multirow[t]{4}{*}{ Nonanal } & 1105.0 & $\mathrm{AL}$ & $88 \pm 5^{\mathrm{bc}}$ & $100 \pm 8^{\mathrm{Bbc}}$ & $102 \pm 6^{\mathrm{Bb}}$ & $133 \pm 7^{\mathrm{Aa}}$ & $86 \pm 4^{\mathrm{Cc}}$ \\
\hline & & RL & $88 \pm 5^{\mathrm{b}}$ & $99 \pm 11^{\mathrm{Bb}}$ & $107 \pm 1^{\mathrm{ABb}}$ & $135 \pm 13^{\mathrm{Aa}}$ & $136 \pm 2^{\mathrm{Aa}}$ \\
\hline & & $\mathrm{AV}$ & $88 \pm 5^{c}$ & $127 \pm 3^{\mathrm{Aab}}$ & $115 \pm 4^{\mathrm{Ab}}$ & $128 \pm 7^{\mathrm{Aa}}$ & $131 \pm 4^{\mathrm{Aa}}$ \\
\hline & & $\mathrm{RV}$ & $88 \pm 5^{\mathrm{c}}$ & $82 \pm 2^{\mathrm{Bcd}}$ & $77 \pm 2^{\mathrm{Cd}}$ & $127 \pm 7^{\mathrm{Aa}}$ & $99 \pm 8^{\mathrm{Bb}}$ \\
\hline \multicolumn{8}{|l|}{ Ketones } \\
\hline \multirow[t]{4}{*}{ 3-Octen-2-one } & 1041.7 & $\mathrm{AL}$ & $255 \pm 25^{\mathrm{d}}$ & $314 \pm 17^{\mathrm{ABc}}$ & $390 \pm 23^{\mathrm{Ab}}$ & $461 \pm 27^{\mathrm{Aa}}$ & $472 \pm 23^{\mathrm{Ba}}$ \\
\hline & & RL & $255 \pm 25^{\mathrm{ab}}$ & $255 \pm 22^{\mathrm{BCab}}$ & $229 \pm 23^{\mathrm{Cb}}$ & $313 \pm 31^{\mathrm{Ba}}$ & $291 \pm 14^{\mathrm{Cab}}$ \\
\hline & & $\mathrm{AV}$ & $255 \pm 25^{\mathrm{d}}$ & $339 \pm 21^{\mathrm{Ac}}$ & $427 \pm 9^{\mathrm{Ab}}$ & $463 \pm 8^{\mathrm{Ab}}$ & $508 \pm 10^{\mathrm{Aa}}$ \\
\hline & & $\mathrm{RV}$ & $255 \pm 25^{\mathrm{abc}}$ & $238 \pm 33^{\mathrm{Cbc}}$ & $282 \pm 4^{\mathrm{Bab}}$ & $226 \pm 14^{\mathrm{Cc}}$ & $291 \pm 20^{\mathrm{Ca}}$ \\
\hline \multirow[t]{4}{*}{ 2-Nonanone } & 1093.4 & $\mathrm{AL}$ & $49 \pm 9^{d}$ & $170 \pm 7^{\mathrm{Bc}}$ & $167 \pm 12^{\mathrm{Bc}}$ & $335 \pm 21^{\mathrm{Ca}}$ & $207 \pm 1^{\mathrm{Ab}}$ \\
\hline & & RL & $49 \pm 9^{d}$ & $121 \pm 4^{\mathrm{Cc}}$ & $148 \pm 19^{\mathrm{Bc}}$ & $310 \pm 29^{\mathrm{Ca}}$ & $219 \pm 19^{\mathrm{Ab}}$ \\
\hline & & $\mathrm{AV}$ & $49 \pm 9^{\mathrm{e}}$ & $275 \pm 6^{\mathrm{Ac}}$ & $413 \pm 35^{\mathrm{Ab}}$ & $583 \pm 70^{\mathrm{Ba}}$ & $163 \pm 4^{\mathrm{Bd}}$ \\
\hline & & RV & $49 \pm 9^{c}$ & $124 \pm 3^{\mathrm{Cb}}$ & $109 \pm 6^{\mathrm{Cb}}$ & $2170 \pm 194^{\mathrm{Aa}}$ & $121 \pm 13^{\mathrm{Cb}}$ \\
\hline \multirow[t]{4}{*}{ 2-Decanone } & 1192.0 & $\mathrm{AL}$ & $\mathrm{Nd}$ & $33 \pm 2^{\mathrm{Ac}}$ & $42 \pm 3^{\mathrm{Ab}}$ & $52 \pm 3^{\mathrm{Ba}}$ & $39 \pm 0^{\mathrm{Ab}}$ \\
\hline & & RL & $\mathrm{Nd}$ & $29 \pm 4^{\mathrm{Ab}}$ & $33 \pm 5^{\mathrm{Bb}}$ & $51 \pm 5^{\mathrm{Ba}}$ & $34 \pm 4^{\mathrm{Bb}}$ \\
\hline & & $\mathrm{AV}$ & $\mathrm{Nd}$ & $28 \pm 1^{\mathrm{Abc}}$ & $29 \pm 1^{\mathrm{Bb}}$ & $52 \pm 4^{\mathrm{Ba}}$ & $24 \pm 0^{\mathrm{Cc}}$ \\
\hline & & $\mathrm{RV}$ & $\mathrm{Nd}$ & $11 \pm 4^{\mathrm{Bc}}$ & $20 \pm 1^{\mathrm{Cb}}$ & $126 \pm 23^{\mathrm{Aa}}$ & $22 \pm 0^{\mathrm{Cb}}$ \\
\hline \multicolumn{8}{|l|}{ Alcohols } \\
\hline \multirow[t]{4}{*}{ 1-Octen-3-ol } & 982.4 & $\mathrm{AL}$ & $266 \pm 43^{b}$ & $429 \pm 29^{\mathrm{Bb}}$ & $500 \pm 25^{\mathrm{Aba}}$ & $565 \pm 39^{\mathrm{Aa}}$ & $541 \pm 27^{\mathrm{Ba}}$ \\
\hline & & RL & $266 \pm 43^{d}$ & $406 \pm 19^{\mathrm{Bc}}$ & $427 \pm 54^{\mathrm{Bbc}}$ & $514 \pm 46^{\mathrm{ABab}}$ & $559 \pm 26^{\mathrm{Ba}}$ \\
\hline & & $\mathrm{AV}$ & $266 \pm 43^{c}$ & $545 \pm 29^{\mathrm{Ab}}$ & $521 \pm 11^{\mathrm{Ab}}$ & $545 \pm 32^{\mathrm{Ab}}$ & $698 \pm 23^{\mathrm{Aa}}$ \\
\hline & & $\mathrm{RV}$ & $266 \pm 43^{b}$ & $409 \pm 63^{\mathrm{Ba}}$ & $443 \pm 27^{\mathrm{Aba}}$ & $425 \pm 15^{\mathrm{Ba}}$ & $442 \pm 24^{\mathrm{Ca}}$ \\
\hline \multirow[t]{4}{*}{ 1-Pentanol } & 770.4 & $\mathrm{AL}$ & $174 \pm 7^{\mathrm{d}}$ & $265 \pm 13^{\mathrm{Bc}}$ & $333 \pm 10^{\mathrm{Ab}}$ & $420 \pm 35^{\mathrm{Aa}}$ & $368 \pm 14^{\mathrm{Ab}}$ \\
\hline & & RL & $174 \pm 7^{\mathrm{d}}$ & $225 \pm 19^{\mathrm{Cc}}$ & $252 \pm 16^{\mathrm{Bbc}}$ & $279 \pm 26^{\mathrm{Bb}}$ & $403 \pm 19^{\mathrm{Aa}}$ \\
\hline & & AV & $174 \pm 7^{\mathrm{c}}$ & $322 \pm 11^{\mathrm{Ab}}$ & $307 \pm 34^{\mathrm{ABb}}$ & $381 \pm 23^{\mathrm{Aab}}$ & $441 \pm 78^{\mathrm{Aa}}$ \\
\hline & & RV & $174 \pm 7^{\mathrm{b}}$ & $257 \pm 14^{\mathrm{BCa}}$ & $256 \pm 28^{\mathrm{Ba}}$ & $197 \pm 12^{\mathrm{Cb}}$ & $240 \pm 10^{\mathrm{Ba}}$ \\
\hline \multirow[t]{4}{*}{ 2-Nonanol } & 1100.3 & $\mathrm{AL}$ & $4 \pm 1^{\mathrm{c}}$ & $18 \pm 1^{\mathrm{Bb}}$ & $20 \pm 0^{\mathrm{Ab}}$ & $24 \pm 3^{\mathrm{Ca}}$ & $20 \pm 0^{\mathrm{Bab}}$ \\
\hline & & RL & $4 \pm 1^{\mathrm{e}}$ & $12 \pm 2^{\mathrm{Cd}}$ & $19 \pm 1^{\mathrm{Ac}}$ & $31 \pm 2^{\mathrm{Ca}}$ & $26 \pm 1^{\mathrm{Ab}}$ \\
\hline & & $\mathrm{AV}$ & $4 \pm 1^{\mathrm{c}}$ & $22 \pm 1^{\mathrm{Ab}}$ & $20 \pm 1^{\mathrm{Ab}}$ & $85 \pm 17^{\mathrm{Ba}}$ & $19 \pm 0^{\mathrm{Cb}}$ \\
\hline & & RV & $4 \pm 1^{\mathrm{d}}$ & $7 \pm 1^{\mathrm{Dc}}$ & $10 \pm 0^{\mathrm{Bb}}$ & $813 \pm 63^{\mathrm{Aa}}$ & $10 \pm 2^{\mathrm{Db}}$ \\
\hline \multicolumn{8}{|l|}{ Pyrrole-derivative } \\
\hline \multirow[t]{4}{*}{ 1-Methyl-1 $H$-pyrrole } & 746.2 & $\mathrm{AL}$ & $179 \pm 9^{c}$ & $265 \pm 18^{\mathrm{Ab}}$ & $240 \pm 3^{\mathrm{Bb}}$ & $273 \pm 28^{\mathrm{Bb}}$ & $495 \pm 12^{\mathrm{Aa}}$ \\
\hline & & RL & $179 \pm 9^{d}$ & $261 \pm 19^{\mathrm{Ac}}$ & $290 \pm 21^{\mathrm{Abc}}$ & $435 \pm 33^{\mathrm{Aa}}$ & $327 \pm 25^{\mathrm{Bb}}$ \\
\hline & & $\mathrm{AV}$ & $179 \pm 9^{b}$ & $187 \pm 16^{\mathrm{Bb}}$ & $183 \pm 12^{\mathrm{Bc}}$ & $268 \pm 2^{\mathrm{Ba}}$ & $327 \pm 49^{\mathrm{Ba}}$ \\
\hline & & $\mathrm{RV}$ & $179 \pm 9^{c}$ & $225 \pm 13^{\mathrm{ABab}}$ & $199 \pm 17^{\mathrm{Cbc}}$ & $188 \pm 4^{\mathrm{Cc}}$ & $245 \pm 10^{\mathrm{Ca}}$ \\
\hline
\end{tabular}

Results expressed as mean \pm standard deviation $(n=3)$ of the peak area (adimensional unit). Means followed by different superscript upper-case letters within the same column are significantly different. Means followed by different superscript lower-case letters within the same row are significantly different. Statistical tests used: one-way ANOVA and Tukey's test, with a level of confidence of 0.05. LRI: Linear retention index. AL: Ambient conditions and loose packing; RL: Refrigerated temperature and loose packing; AV: Ambient conditions and vacuum packing: RV: Refrigerated temperature and vacuum packing. *Identification confirmed by comparing mass spectrum and retention time with reference standard. 
oxidation product formation (Barriuso et al., 2013). In this study, hexanal formation remained low for RV throughout storage, while, after four months, it increased to close to $100 \%$ for RL, despite the low PV and tendency for radical formation at that stage, and 72 and $83 \%$ for AV and AL, respectively. Therefore, vacuum packing using LDPE pouches combined with refrigeration was efficient to reduce the formation of this saturated VAC, which is relevant in fresh Brazil nut kernels (Clark and Nursten, 1976), but when present in considerable amounts, it is related to rancidity (Zajdenwerg et al., 2011). The increased efficiency of refrigeration when combined with vacuum packing to retard hexanal formation was also observed in hazelnuts and walnuts stored under similar conditions during long-term storage (Jensen et al., 2003; Ghirardello et al., 2016).

Except for hexanal, there is a lack of studies which monitor the formation of other volatiles during storage in foods (Barriuso et al., 2013). Although presenting relevant peak areas, the formation of trans-2-heptenal, which is also a product from linoleic acid oxidation (Ullrich and Grosch, 1987), remained low for RV, and increased by only 21 and $30 \%$ at the end of storage for $\mathrm{AL}$ and $\mathrm{AV}$, respectively; while for RL it remained low for two months and increased little after that. The low formation rate of trans-2-heptenal contrasts with the sharp increase observed in cold-pressed Brazil nut oils stored at room temperature and exposed to light for $12 \mathrm{~h}$ a day (Sartori et al., 2018). Since the nuts were stored in the dark in the present study, these results suggest that trans-2-heptenal is majorly formed during the photooxidation (Lee and Min, 2010) of these nuts.

On the other hand, the formation of trans2-octenal, which is also formed during linoleic acid oxidation and may present a lower threshold than hexanal (Ullrich and Grosch, 1987), increased by 80, 143, 153 and $294 \%$ for RV, AV, AL and RL, respectively, after four months. Finally, nonanal formation tended to increase for RL and $\mathrm{AV}$, while no clear tendency could be observed for AL and RV.

Ketones generally have low thresholds and may contribute to the flavor profile of foods. The formation of 3-octen-2-one was continuously increased in the kernels stored under ambient conditions (AL and $\mathrm{AV}$ ); while it remained low in the kernels stored under refrigeration (RL and $\mathrm{RV}$ ), which indicates a clear effect of temperature. 3-Octen-2-one occurs as unsaturated ketone formed during linoleic acid autoxidation (Ullrich and Grosch, 1987), and therefore, may contribute to the flavor deterioration of the kernels. 2-Nonanone and 2-decanone were previously identified in Brazil nut extracts and their flavors were assessed as peanutty/fruity and green/ fruity, respectively (Clark and Nursten, 1976), thus probably not related to oxidative deterioration.

The formation of 1-octen-3-ol and 1-pentanol increased for all treatments, but less for RV (Table 3).
These short-chain alcohols are products of the decomposition of linoleic acid hydroperoxides (Ullrich and Grosch, 1987) and thereby may affect off-flavor formation in the kernels. 2-Nonanol has been identified in Brazil nut extracts, although its aroma has not yet been assessed (Clark and Nursten, 1976). It is worth noting that some samples showed outstanding peak areas for 2-nonanol (AV and RV after 3 months), as well as for 2-nonanone (AV after 2 and 3 months, and RV after 3 months) and 2-decanone (RV after 3 months), which suggests that their formation may be affected by factors other than packaging atmosphere, temperature and time of storage.

Pyrrole-derivatives are heterocyclic aromatic compounds that may be products of the interaction between amino acids and aliphatic aldehydes (Adams et al., 2005). The 1-methyl-1H-pyrrole, which was also identified in fresh and dried pistachios (Georgiadou et al., 2015), was likely formed during the drying process and its formation kept increasing during storage for three of the treatments, except for RV.

Overall, with the exception for 3-octen-2-one, the effects of the considered storage time, temperature and atmosphere on VAC formation were shown to be quite different from the tendency of lipid free radicals and primary lipid oxidation product formation, which were affected only by temperature. For off-flavor VACs, packing and temperature conditions may act synergistically, since vacuum packing with refrigeration lowered the contents of some of them (hexanal, trans-2-octenal, 1-octen-3-ol and 1-pentanol), while vacuum packing at room temperature or lose packing under refrigeration seemed to even foster the formation of other VACs (nonanal and 1-octen-3-ol for the former, trans-2-octenal and nonanal, for the latter). To our best knowledge, there are no previous reports on this development, so the reasons for that still remain unclear.

\subsection{Sensory analysis}

Sensory analysis was conducted to verify the effect of undergoing chemical changes on rancidity and the results for rancid odor are shown in Table 4. No statistically significant changes were noticed among the samples during the whole storage period, likely due to the early stage of oxidation in the samples, which could be represented by PV (Section 3.3.). Zajdenwerg et al., (2011) reported that trained assessors identified oxidized odor in Brazil nuts stored at $80^{\circ} \mathrm{C}$ with a PV of 9.9 meq $\mathrm{O}_{2} / \mathrm{kg}$, which is comparable to the highest PV found in this study ( $9.86 \mathrm{meq} \mathrm{O}_{2} / \mathrm{kg}$ for AL 4 months); while untrained assessors (consumers) identified the same attribute only when PV was higher than $17 \mathrm{meq} \mathrm{O}_{2} / \mathrm{kg}$, which indicates that consumers are used to eating oxidized Brazil nut kernels. 
Tendency of lipid radical formation and volatiles in lose or vacuum-packed Brazil nuts stored at room temperature • 9

TABLE 4. Rancid odor attributed by the trained assessors to Brazil nut samples with respect to storage conditions and period

\begin{tabular}{lccccc}
\hline Treatment & Time zero & 1 month & 2 months & 3 months & 4 months \\
\hline AL & & $1.4 \pm 0.9$ & $1.3 \pm 0.4$ & $2.0 \pm 0.7$ & $1.6 \pm 0.5$ \\
RL & $1.4 \pm 0.5$ & $1.2 \pm 0.4$ & $2.0 \pm 0.7$ & $1.3 \pm 0.4$ \\
AV & $1.7 \pm 0.3$ & $1.8 \pm 0.8$ & $1.5 \pm 0.5$ & $1.8 \pm 0.8$ & $1.8 \pm 0.8$ \\
RV & & $1.4 \pm 0.5$ & $2.0 \pm 1.0$ & $1.3 \pm 0.4$ & $1.6 \pm 0.9$ \\
\hline
\end{tabular}

No significant changes were detected. Statistical tests used: one-way ANOVA and Tukey's test, with a level of confidence of 0.05. Data from time zero is an average of the five samples used. AL: Ambient conditions and loose packing; RL: Refrigerated temperature and loose packing; AV: Ambient conditions and vacuum packing; RV: Refrigerated temperature and vacuum packing.

\section{CONCLUSIONS}

The use of refrigeration, whether combined with lose packing or vacuum packing, was effective in reducing the tendency of radical formation, as well as peroxides and conjugated dienes in Brazil nut kernels during storage. The formation of off-flavor VACs was also affected by storage conditions and the use of refrigeration reduced the formation of one VAC, the 3-octen-2-one. However, the combination of refrigeration and vacuum packing, even when LDPE pouches with high OTR were used, reduced the formation of hexanal, which is a major contributor to flavor deterioration, as well as the formation of other off-flavor VACs, and thus should be recommended for Brazil nut kernel storage.

\section{ACKNOWLEDGMENTS}

The authors acknowledge financial support from the Coordination for the Improvement of Higher Education Personnel (CAPES); and the National Council of Technological and Scientific Development (CNPq) [grant number 201635/2015-1].

\section{REFERENCES}

Adams A, Borrelli RC, Fogliano V, Kimpe N de. 2005. Thermal degradation studies of food melanoidins. J. Agric. Food Chem. 53, 4136-4142. https://doi.org/10.1021/jf047903m

Andersen ML, Skibsted LH. 2018. ESR Spectroscopy for the Study of Oxidative Processes in Food and Beverages, in Webb GA (Ed.) Modern Magnetic Resonance, Springer Int. Pub., pp. 1-14. https://doi.org/10.1007/ 978-3-319-28275-6_25-1

Andersen ML, Skibsted LH. 2002. Detection of early events in lipid oxidation by electron spin resonance spectroscopy. Eur. J. Lipid Sci. Technol. 104, 65-68. https:// doi.org/10.1002/1438-9312(200201)104:1<65::AIDEJLT65 $>3.0$. CO $22-3$

Babushok VI, Linstrom PJ, Zenkevich IG. 2011. Retention indices for frequently reported compounds of plant essential oils. J. Phys. Chem. Ref. Data 40, 043101. https://doi. org/10.1063/1.3653552

Barriuso B, Astiasarán I, Ansorena D. 2013. A review of analytical methods measuring lipid oxidation status in foods: a challenging task. Eur. Food Res. Tech. 236, 1-15. https:// doi.org/10.1007/s00217-012-1866-9

Camargo AC de, Regitano-d'Arce MAB, Alencar SM de, Canniatti-Brazaca SG, Vieira TMF de Souza, Shahidi F. 2016. Chemical Changes and Oxidative Stability of Peanuts as Affected by the Dry-Blanching. J. Am. Oil Chem. Soc. 93, 1101-1109. https://doi.org/10.1007/s11746-016-2838-1

Choe E, Min DB. Mechanisms and Factors for Edible Oil Oxidation. 2006. Comp. Rev. Food Sci. Food Safety. 5, 169-186. https://doi.org/10.1111/j.1541-4337.2006.00009.x

Chun J, Lee J, Eitenmiller RR. 2005. Vitamin E and oxidative stability during storage of raw and dry roasted peanuts packaged under air and vacuum. J. Food Sci. 70, 292-297. http://doi.org/10.1111/j.1365-2621.2005.tb07176.x

Clark RG, Nursten HE. 1976. Volatile flavour components of Brazil nuts Bertholletia excelsa (Humpl. and Bonpl.). J. Sci. Food Agri. 27, 713-720. https://doi.org/10.1002/ jsfa. 2740270802

Cochran WG, Cox GM. 1964. Experimental designs. John Wiley \& Sons, London, UK.

Codex Alimentarius. 2001. Codex standard for named vegetable oils, CODEX STAN 210-1999. Codex Alimentarius vol. 8, pp. $11-25$.

Costa PA da, Ballus CA, Teixeira-Filho J, Godoy HT. 2010. Phytosterols and tocopherols content of pulps and nuts of Brazilian fruits. Food Res. Int. 43, 1603-1606. https://doi. org/10.1016/j.foodres.2010.04.025

Dobarganes MC, Velasco J. 2002. Analysis of lipid hydroperoxides. Eur. J. Lipid Sci. Technol. 104, 420-428. https:// doi.org/10.1002/1438-9312(200207)104:7<420::AIDEJLT420>3.0.CO;2-N

Elmore JS, Mottram DS, Hierro E. 2001. Two-fibre solid-phase microextraction combined with gas chromatography-mass spectrometry for the analysis of volatile aroma compounds in cooked pork. J. Chromatogr. A 905, 233-240. https://doi. org/10.1016/s0021-9673(00)00990-0

Evans JC, Rao KRN, Jackson SK, Rowlands CC, Barratt MD. 1985. Identification of radicals spin-trapped in autoxidized linoleic acids: A high performance liquid chromatography and electron spin resonance study. J. Separation Sci. 8, 829-830. https://doi.org/10.1002/jhrc. 1240081204

FAO - Food and Agricultural Organization of the United Nations. 2013. Multiple-use forest management in the humid tropics: opportunities for sustainable forest management. FAO, Rome, Italy.

FAO - Food and Agricultural Organization of the United Nations. 2017. FAOSTAT Statistical databases. http:// www.fao.org/faostat/en/\#home

Fourie PC, Basson DS. 1989. Predicting occurrence of rancidity in stored nuts by means of chemical analysis. Lebensm Wiss Technol. 22, 251-253.

Georgiadou M, Gardeli C, Komaitis M, Tsitsigiannis DI, Paplomatas EJ, Sotirakoglou K, Yanniotis S. 2015. Volatile profiles of healthy and aflatoxin contaminated pistachios. Food Res. Int. 74, 89-96. http://doi.org/10.1016/j. foodres.2015.03.021

Ghirardello D, Bertolino M, Belviso S, Dal Bello B, Giordano M, Rolle L, Gerbi V, Antonucci M, Spigolon N, Zeppa G. 2016. Phenolic composition, antioxidant capacity and hexanal content of hazelnuts (Corylus avellana L.) as affected by different storage conditions. Post. Biol. Technol. 112, 95-104. https://doi.org/10.1016/j.postharvbio.2015.09.039

Hartman L, Lago RC. 1973. Rapid preparation of fatty acid methyl esters from lipids. Lab. Pract. 22, 475. 
Jensen PN, Sorensen G, Brockhoff P, Bertelsen G. 2003. Investigation of Packaging Systems for Shelled Walnuts Based on Oxygen Absorbers. J. Agric. Food Chem. 51, 4941-4947. https://doi.org/10.1021/jf021206h

Lee J, Min DB. 2010. Analysis of volatile compounds from chlorophyll photosensitized linoleic acid by headspace solidphase microextraction (HS-SPME). Food Sci. Biotech. 19, 611-616. https://doi.org/10.1007/s10068-010-0086-y

Marcuse R, Fredriksson P. 1968. Fat oxidation at low oxygen pressure. I. Kinetic studies on the rate of fat oxidation in emulsions. J. Am. Oil Chem. Soc. 45, 400-7. https://doi. org/10.1007/bf02667120

Miraliakbari H, Shahidi F. 2008. Lipid class compositions, tocopherols and sterols of tree nut oils extracted with different solvents. J. Food Lipids 15, 81-96. https://doi. org/10.1111/j.1745-4522.2007.00104.x

Rayman MP. 2012. Selenium and human health. The Lancet 379 , 1256-1268. https://doi.org/10.1016/s0140-6736(11)61452-9

Ribeiro MAA, Regitano-d'Arce, MAB, Lima UA, Baggio CE. 1993a. Armazenamento da castanha do pará com e sem casca: efeito da temperatura na resistência ao ranço. Scientia Agricola 50, 343-348. https://doi.org/10.1590/ s0103-90161993000300004

Ribeiro MAA, Regitano-d'Arce MAB, Lima UA, Nogueira MCS. 1993b. Storage of canned shelled Brazil nuts (Bertholletia excelsa): effects on the quality. Acta Alimentaria 22, 295-303.

Ribeiro MAA, Soler RM, Regitano-d'Arce MAB, Lima UA. 1995. Shelled Brazil nuts canned under different atmospheres. Ciência Tecnol. Alimentos 15, 105-107.

Rotruck JT, Pope AL, Ganther HE, Swanson AB, Hafeman DG, Hoekstra W. 1973. Selenium: biochemical role as a component of glutathione peroxidase. Science 179 , 588-590. https://doi.org/10.1126/science.179.4073.588

Santos OV, Corrêa NCF, Soares FASM, Gioielli LA, Costa CEF, Lannes SCS. 2012. Chemical evaluation and thermal behavior of Brazil nut oil obtained by different extraction processes. Food Res. Int. 47, 253-258. https://doi. org/10.1016/j.foodres.2011.06.038

Sartori AGO, Sampaio GR, Bastos DHM, Regitano-d'Arce MAB, Skibsted LH. 2018. Volatiles and Tendency of Radical Formation of Cold-Pressed Brazil Nut Oil During
Ambient Storage. 2018. J. Am. Oil Chem. Soc. 95, 721-30. https://doi.org/10.1002/aocs.12073

Shantha NC, Decker EA. 1994. Rapid, sensitive, iron-based spectrophotometric methods for determination of peroxide values of food lipids. JAOAC Int. 77, 421-424.

Thomsen MK, Kristensen D, Skibsted LH. 2000. Electron spin resonance spectroscopy for determination of the oxidative stability of food lipids. J. Am. Oil Chem. Soc. 77, 725-730. https://doi.org/10.1007/s11746-000-0117-2

Ullrich F, Grosch W. 1987. Identification of the most intense volatile flavour compounds formed during autoxidation of linoleic acid. Zeitschrift für Lebensmittel-Untersuchung und Forschung 184, 277-282. https://doi.org/10.1007/ bf01027663

USDA - United States Department of Agriculture. 2015. National Nutrient Database for Standard Reference.

Velasco J, Andersen ML, Skibsted LH. 2004. Evaluation of oxidative stability of vegetable oils by monitoring the tendency to radical formation. A comparison of electron spin resonance spectroscopy with the Rancimat method and differential scanning calorimetry. Food Chem. 85, 623-632. https://doi.org/10.1016/j.foodchem.2003.07.020

Velasco J, Andersen ML, Skibsted LH. 2005. Electron Spin Resonance Spin Trapping for Analysis of Lipid Oxidation in Oils: Inhibiting Effect of the Spin Trap $\alpha$-Phenyl-N-tertbutylnitrone on Lipid Oxidation. J. Agric. Food Chem. 53, 1328-1336. https://doi.org/10.1021/jf049051w

Ventanas S, Estévez M, Delgado CL, Ruiz J. 2007. Phospholipid oxidation, non-enzymatic browning development and volatile compounds generation in model systems containing liposomes from porcine Longissimus dorsi and selected amino acids. Eur. Food Res. Technol. 225, 665-675. https:// doi.org/10.1007/s00217-006-0462-2

Vieira TM, Regitano-d'Arce MA. 1999. Antioxidant concentration effect on stability of Brazil nut (Bertholletia excelsa) crude oil. Arch. Latinoamericanos Nutricion 49, 271-274.

Zajdenwerg C, Branco GF, Alamed J, Decker EA, Castro IA. 2011. Correlation between sensory and chemical markers in the evaluation of Brazil nut oxidative shelf-life. Eur. Food Res. Technol. 233, 109-16. https://doi.org/10.1007/ s00217-011-1493-x 